\title{
Umkm Olahan Telur Bebek Untuk Memenuhi Kebutuhan Gizi Dan Meningkatkan Pendapatan Masyarakat Desawonosari Kecamatan Gadingrejo Kabupaten Pringsewu
}

\author{
Tiar Mirnasari ${ }^{1}$, Nur'aeni $^{1}$, Yuliana Yamin $^{1}$, Samsul Ma'arif $^{1}$ \\ Fakultas Ekonomi Prodi Manajemen Universitas Sang Bumi Ruwa Jurai \\ tiarmirnasari2021@gmail.com,nuraeniharyo@gmail.com,yuliyamin0607@gmail.com,saburaisam@gmail.com
}

\begin{abstract}
Abstrak
Berdasarkan data yang diperoleh dari Kepala Desa Wonosari Kecamatan Gadingrejo Kabupaten Pringsewu, potensi yang dimiliki Desa Wonosari sangat banyak untuk dikembangkan diantaranya: padi, ladang,jagung dan tanaman holtikultura. Selain itu warga juga menekuni berbagai usaha peternakan seperti: ikan lele,nila,mujair dan gurame, sapi, kambing juga itik atau bebek. Adapun jumlah Rumah Tangga Peternak(RTP) bebek di Desa Wonosari mencapai 30orang dan tergabung dalam 3 kelompok yang tersebar dibeberapa Dusun.Tujuan penelitianuntuk mengetahuisistemcara beternak itik, jumlahpendapatanusaha ternak itik,apakahusaha ternak itik layak atau tidak untuk dikembangkan secara ekonomis, masalah-masalah yang dihadapi dalam beternak itik dan upaya-upaya yang dilakukan untuk menghadapi masalah-masalah dalam beternak itik. Permasalahan yang dihadapi adalah mitra merupakan kumpulan peternak unggas skala rumahan dengan pendapatan perkapita sangat rendah, sebagai dampak turunnya harga karet sejak 3(tiga) tahun yang lalu, mitra tidak memahami usaha ternak bebek yang memiliki peluang bisnis cukup menjanjikan saat ini, mitra tidak memiliki ilmu pengetahuan untuk membuat telur asinyang dapat dijadikan untuk menambah pendapatan serta menambah asupan gizi masyarakat setiap hari. Target yang telah dicapai yaitu kegiatan ini telah mampu meningkatkan pendapatan dengan pemasaran yang inovatif. Target lain yang telah dicapai yaitu kegiatan ini telah dipublikasi di media massa dan juga telah dibuat dokumentasi dalam bentuk foto dan video. Target berikutnya yang sedang dalam proses yaitu mempublikasikan hasil pengabdian dalam jurnal pengabdian yang sudah terakreditasi.
\end{abstract}

KataKunci: Kebutuhan Gizi, Meningkatan Pendapat, UMKM, Telur Bebek

\begin{abstract}
Based on data obtained from the Head of Wonosari Village, Gadingrejo District, Pringsewu Regency, the potential of Wonosari Village is very much to be developed including: rice fields, corn and horticultural crops. In addition, residents also pursue various livestock businesses such as: catfish, tilapia, mujair and gourami, cows, goats as well as ducks or ducks. The number of Duck Breeding Households (RTP) in Wonosari Village reached 30 people and were divided into 3 groups spread across several hamlets. The purpose of the research was to determine the system of raising ducks, the amount of income from duck farming, whether duck farming is feasible or not to be developed economically, the problems faced in raising ducks and the efforts made to deal with the problems faced by ducks. is a partner which is a collection of home-scale poultry farmers with very low per capita income, as a result of the fall in rubber prices since 3 (three) years ago, partners do not understand the duck farming business which has quite promising business opportunities at this time, partners do not have the knowledge to make eggs which can be used to increase income and increase people's daily nutritional intake. The target that has been achieved is that this activity has been able to increase revenue with innovative marketing. Another target that has been achieved is that this activity has been published in the mass media and documentation in the form of photos and videos has also been made. The next target in the process is to publish the results of service in an accredited service journal.
\end{abstract}

Keywords: Nutritional Needs, Increasing Income, MSMEs, Duck Eggs 


\section{PENDAHULUAN}

Berdasarkan data yang diperoleh dari Kepala Desa Wonosari Kecamatan Gadingrejo Kabupaten Pringsewu, potensi yang dimiliki Desa Wonosari sangat banyak untuk dikembangkan diantaranya:padi,ladang,jagung dan tanaman holtikultura. Selain ituwarga juga menekuni berbagai usaha peternakan seperti: ikan lele,nila,mujairdangurami,sapi,kambing jugaitikataubebek. Adapun jumlah Rumah Tangga Peternak(RTP) bebek di Desa Wonosari mencapai 30orang dan tergabung dalam 3 kelompok yang tersebar dibeberapa Dusun.

Selama ini hasil telur bebeklangsung dijual ke pasar atau diambil oleh pengepul untuk dikirim ke luar daerah. Kurangnya ilmu pengetahuan dalam menghasilkan produk olahan telur bebek membuat semua warga hanya menjualnya begitu saja. Sehingga pendapatan yang diperoleh tidak maksimal, bahkan kadang kala hanya cukup untuk mengembalikan biaya produksi. Pengolahan hasil peternakan khususnya komoditas telurbebek menjadi salah satu alternatif untuk meningkatkan nilai gizi masyarakat. Teknologi pengolahan yang digunakan sederhana dan dapat diterapkan ditempat peternak sentra produksi. Dengan teknologi penanganan pasca panen yaitu pengolahan hasil dapat meningkatkan kelancaran pemasaran. Selain mendapatkan nilai tambah, kegiatan pengolahan hasil juga membuka peluang bagi pengembangan agribisnis dipedesaan.

Penelitian untuk mengetahui sistem cara beternak itik, jumlah pendapatan usaha ternak itik,apakah usaha ternak itik layak atau tidak untuk dikembangkan secara ekonomis, masalahmasalah yang dihadapi dalam beternak itik dan upaya-upaya yang dilakukan untuk menghadapi masalah-masalah dalambeternakitik.

\section{METODE PELAKSANAAN}

\section{Metode Pendekatan}

Metode pendekatan pada program yang dilaksanakan adalah: a) Melakukan pendataan terhadap peternak unggas rumahan disetiap Dusun lebih spesifik agar diketahui besar potensi real yang terdapat di Desa tersebut, sehingga dapat untuk menghitung besar produksi. b) Melakukan pendekatan dengan pemerintah daerah setempat serta pengusaha lokal guna mendukung keberhasilan program. c) Mendatangkan pelatih untuk mensosialisasikan hal-hal yang perlu dipersiapkan dalam beternak bebek, juga membuat olahan telur bebek menjadi telur asin agar lebih awet dan tahan lama. d) Melakukan pelatihan cara pembuatan telur asin yang berkualitas dengan memanfaatkan potensi lokal seperti: abu gosok dan tanah merah agar dapat menekan biaya produksi. Kegiatan ini dapat menstimulasi Mitra untuk menekuni bisnis peternakan, sehingga dapat bangkit dari keterpurukan ekonomi. e) Mengoptimalkan bahan baku yang ada di sekitar wilayah Mitra, guna meminimalisasi cost/biaya produksi dalam pembuatan produk olahan. Hal ini dimaksudkan untuk memperoleh keuntungan yang lebih besar.

\section{Prosedur kerja}




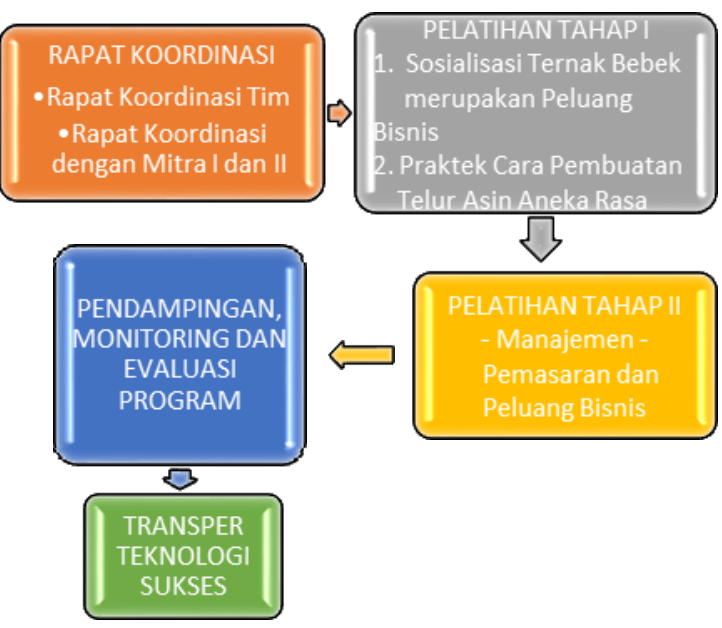

\section{Partisipasi Mitra}

Gambar1. Tahapan SosialisasiProgram

Mitra berpartisipasi aktif dalam setiap rencana kegiatan. Sebelum proposal ini dibuat terlebih dahulu melakukan survei awal dan wawancara untuk mengetahui kondisi mitra dan halhal apa yang sangat diperlukan Mitra. Pelatihan bisnis peternakan bebek petelur juga pembuatan telur asin merupakan kegiatan yang disepakati oleh Tim dan Mitra dan rencananya akan dilaksanakan dilokasi Mitra. Dalam hal ini Mitra menyediakan kandang bebek yang didesain oleh Tim Pengabdian serta telur bebek hasil ternak.Untuk kegiatan pelatihan manajemen produksi juga pemasaran merupakan usulan dari Tim yang telah disepakati oleh Mitra, guna membekali masyarakat dalam pengelolaan usaha olahan telur asin agar mampu bangkit dari keterpurukan ekonomi selama bertahun-tahun. Selanjutnya Mitra akan diperkenalkan dengan metode-metode promosi yang berkaitan dengan berbagai olahan telur asin seperti: telur asin rebus, bakar/panggang dan asam.Dalam pelaksanaan program, Mitra berasal 2 kelompok peternak unggas rumahan di Desa Wonosari. Mitra juga dilibatkan dalam evaluasi program untuk menilai sejauh mana program telah dilaksanakan, apa dampak yang timbul setelah dilakukan berbagai kegiatan program, dan apa yang perlu dibenahi atau dikembangkan pada tahun mendatang. Mitra nantinya diharapkan menjadi acuan dalam share knowlage pada seluruh masyarakat di Kecamatan Tiga juhar. Tentunya, sangat diharapkan bahwa rangkaian kegiatan yang dilaksanakan dapat membantu meningkatkan perekonomian Mitra pada khususnya dan masyarakat Desa Rumah Sumbul pada umumnya.

\section{HASIL DAN PEMBAHASAN}

Kegiatan yang dilakukan oleh tim PKM Olahan Telur Bebek Untuk Memenuhi Kebutuhan Gizi Dan Meningkatkan Pendapatan Masyarakat Desa Rumah Sumbul, melalui tahapan sebagai berikut:

\section{Tahap Sosialisasi Ternak Bebek Petelur Merupakan Peluang Bisnis Menjanjikan}

Pada tahap ini dilakukan sosialisasi tentang peluang bisnis peternaka bebek. Masyarakat diharapkan dapat menjadi wirausaha baru dalam bidang ternak bebek petelur dengan mengembangkan potensi alam yang dimiliki. Hal ini sebagai modal awal untuk merintis bisnis disisi hilir yaitu pembuatan telur asin yang memiliki nilai ekonomi lebih tinggi dari pada dijual dalam bentuk telur mentah biasa. Disamping itu juga lebih awet dan tahan lama jika tidak terjual. Sehingga dapat meminimalisasi kerugian Mitra dalam usahanya.

\section{Tahap Pelatihan Pembuatan Berbagai Olahan dengan Bahan Dasar Telur Bebek}


Pada tahap ini Mitra akan melakukan praktek langsung tentang bagaimana teknik dalam pembuatan berbagai olahan berbahan dasar telur bebek. Kegiatan iniakan diselenggarakan dirumah Mitra. Acara pelatihan ini dihadiri oleh seluruh anggota kelompok peternak unggas rumahan yang adadi Desa tersebut.

Hal-hal yang perlu disiapkan antara lain: 1) Alat yang digunakan adalah infokus dan alat pendukung lainn ya yang berguna saat pen yampaian materi berlangsung. 2) Bahan yang digunakan dalam berbagai olahan telur bebek yang akan dipraktekkan adalah telur bebek, garam, abu gosok, tanah/batubata merah dan tunggu tanah liat. 3) Handout mengenai cara pembuatan telur asin yang terdiri dari judul, tujuan, alat dan bahan, cara pembuatan, penjelasan mengenai produk olahan telur yang berkualitas, kelebihan dan keunggulan produk olahan yang dihasilkan, dan hal-hal lain yang perlu diperhatikan. Handout disajikan dalam bentuk contoh produk jadi. Melalui handout diharapkan para peserta pelatihan lebih cepat memahami apa yang disampaikan oleh Tim Pengabdian.

\section{Demonstrasi Pembuatan Telur Bebek Asin}

Berikut proses pembuatan telur asin skala industri rumah tangga, Bahan: 1) Telur bebek mentah. 2) Kertas Pasir fungsinya untuk menghaluskan kulit telur. 3)Garam. 4) Abu Sekam Padi/Tanah Liat. 5) wadah

\section{Langkah-langkah dalam pembuatan telur asin}

1. Siapkan beberapa Telur bebek

2. Gosok dengan kertas pasirf ungsinya untuk menghaluskan kulit telur.

3. Siapkan Garam dan Abu Padi.

4. Pembungkusan telur menggunakan adonan abu padi yang telah di campur garam dan air.

5. Menyimpan telur asin dalam wadah selama 15 hari.

\section{Demonstrasi Pembuatan Telur Bebek Asin Rasa Pedas}

Berikut proses pembuatan telur asin rasa pedas skala industri rumah tangga. Bahan: 1) Telur bebek mentah. 2) Kertas Pasir fungsinya untuk Menghaluskan kulit telur. 3) Garam. 4) Air. 5) Cabai. 6) Serai. 7) Jahe. 8) Wadah.

\section{Langkah-langkah dalam pembuatan telur asin rasa pedas:}

1. Siapkan Telur bebek

2. Gosok dengan kertas pasir fungsinya untuk menghaluskan kulit telur.

3. Cabai Merah keriting di Belah dan di Giling

4. Garam dilarutkan dalam air

5. Rebus bahan bahan seperti cabai, jahe, serai dan garam.

6. Setelah direbus diamkan bumbunya hingga dingin lalu masukkan telur bebek yang sudah digosok dengan kertas pasir.

7. Telur siap disimpan.

\section{Tahap Pelatihan Manajemen Produksi dan Pemasaran Produk Olahan}

Pengetahuan tentang manajemen produksi dan Pemasaran produk olahan sangat penting untuk dilakukan. Hal ini berkaitan dengan bekerlanjutan program serta target luaran yang diinginkan. Mengingat latar belakang Mitra yang mayoritas petani dan buruh, maka Tim Pengabdian melakukan sosialisasi berulang kali sampai Mitra mampu menghitung cost dan hasil produksi juga menguasi sistem pemasarannya. Metode tersebut dilakukan guna menciptakan kepercayaan Mitra kepada TimPengabdian, sehingga tercipta suatu kerjasama yang baik antara Perguruan Tinggi dengan masyarakat dalam menumbuhkan agroindustri dipedesaan. 


\section{Tahap monitoring}

Tahap monitoring dilakukan guna memantau seberapa besar tingkat keberhasilan program. Dengan demikian tujuan dari tahap monitoring adalah sebagaiberikut:

a. Melihat perkembangan program yang telah dilaksanakan.

b. Mengetahui kendala yang ada dalam proses pelaksanaan program.

c. Mencari solusi terhadap masalah yang ada, sehingga program Pengabdian yang dilaksanakan benar-benar efektif dan maksimal serta bersinergis.

\section{Tahap pendampingan}

Mitra akan terus didampingi dalam menyelesaian permasalahan yang timbul berkaitan dengan pengembangan produk serta pemasaran produk hingga Mitra benar-benarmandiri.

\section{Tahap Evaluasi Program}

Tahap evaluasi dilakukan untuk mengevaluasi tingkat keberhasilan pelaksanaan juga mengetahui kekurangan dalam pelaksanaan program. Melalui proses evaluasi, kekurangan yang terjadi dalam pelaksanaan program dapat diperbaiki menjadi lebih baik. Tahap ini dilakukan oleh Tim Peneliti (Dosen dan Mahasiswa) bersama Mitra dan aparatur Desa yang didasarkan oleh indikator keberhasilan program.

\section{Tahap akhir penyusunan laporan pengabdian.}

Penyusunan laporan dilakukan pada akhir program guna memaparkan agenda-agenda yang dilakukan selama program berlangsung yang disertai dengan dokumentasi di lapangan sebagai wujud nyata program terlaksana dengan baik.

\section{KESIMPULAN}

Pelaksanaan kegiatan pengabdian masyarakat olahan telur bebek di Desa Rumah Sumbul telah berjalan dengan baik dengan beberapa kegiatan yang telah dilakukan adalah penyuluhan dan diskusi, praktek pembuatan olahan telur bebek,serta pendampingan, dengan produk olahan telur asin dua rasa yaitu: rasa asin dan rasa pedas.

Masyarakat sasaran yaitu ibu-ibu pengajian dusun Bintang Asih memberikan tanggapan yang sangat positif dengan berpartisipasi aktif dalam mengikuti seluruh kegiatan dengan sebaik-baiknya. Selain itu, menyampaikan apresiasi kepada Tim Pelaksana karena telah memberikan wawasan, pengalaman dan ketrampilan warga sehingga dapat menjadi bekal untuk berwirausaha agar lebih mandiri dan tidak tergantung pada orang lain.

\section{Saran}

Pemberdayaan masyarakat terutama kepada masyarakat Desa Rumah Sumbul sebaiknya dilakukan secara komprehensif dengan melibatkan berbagai unsur melalui berbagai organisasi sosial kemasyarakatan dan dilakukan secara berkelanjutan dengan implementasi berbagai bidang.

\section{UCAPAN TERIMAKASIH}


Seminar Nasional Penelitian dan Pengabdian kepada Masyarakat Universitas Sang Bumi Ruwa Jurai Tahun 2020

Terima kasih penulis ucapkan kepada semua pihak yang telah membantu pelaksanan kegiatan pengabdian kepada masyarakat diantaranya: 1) Universitas Sang Bumi Ruwa Jurai dan LPPM yang telah turut serta memberikan kesempatan kepada tim pengabdi untuk melaksanakan pengabdian. 2) Peternak telur Gading Rejo

\section{DAFTAR PUSTAKA}

Balai Pusat Penelitian Pertanian.1992. Lima Tahun Penelitian dan Pengembangan Pertanian. Jakarta: Departemen Pertanian.

Hamdan,2010," Kelayakan Usaha Peternakan Itik Petelur Dengan Pemanfaatan Keong Mas Sebagai Sumber Pakan Alternatif", Skripsi Departemen Agribisnis Fakultas Ekonomi Dan Manajemen IPB.

Hartono, D. 1998. Pengaruh Galur dan Tingkat Kandungan Protein Ransum Terhadap Produksi dan Kualitas Telur Itik Lokal. Karya Ilmiah. Fakultas Peternakan. Institut Pertanian Bogor, Bogor.

Harahap, A. Arbi, A. Tami, D. Azhari,W. Dan Tan Bandaro, D.DT.1978. Pengaruh Manajemen Terhadap Produksi Telur Itik di Sumatera Barat.

Kardjono. 1998. Pakan Alternatif Itik Petelur. Tribus No.339 Tahun XXIX. Murtidjo, B. A., 1990, "BeternakItik", Yogyakarta.

Prasetyo,L. H.dan Susanti, T. 1997. PersilanganTimbal Balik AntaraItikTegal dan Itik Mojosari:I.AwalPertumbuhan danAwalBertelur. JornalllmuTernak dan Veteriner2 (3):h.152-153.Jakarta:DepartemenPertanian.

Purwanti. 1999. Peternakan Itik Rakyat Dalam Pembangunan Regional Di Karawang.KaryaIlmiah.FacultasPeternakan.InstitutPertanianBogor,Bogor.

Purnomo,E.2001. Analisa Usaha Ternak Itik Petelur Anggota Koperasi Ternak Itik Wirausaha Di Kota Jakarta Utara [Skripsi]. Bogor: Fakultas Peternakan, Institut Pertanian Bogor.

Rasyaf,M.1986.Beternak Itik. Yogyakarta: Penerbit Kanisius

SuharnoB,2013, “Beternak itik secara intensif,'Penerbit Penebar Swadaya. Edisi 2. Tahun 2013. Sinaga,2015, “Analisis Usaha Ternak Itik Petelur Studi Kasus Kec. Bandar Khalifah Kab. Serdang Bedagai“, SkripsiUSU.

Syarief,1993,“Teknologi Penyimpanan Pangan”,Arcan,Jakarta.

SalmanM,2014, “Analisis Usaha Pembuatan Telur Asin Di Kota Madya Mataram Nusa Tenggara Barat (NTB),'Jurnal Agribisnis Vol 12 No.1 uni2014.

Samosir,D.J.1983.Ilmu Ternak Itik.Jakarta:PT.Gramedia dan PemdaD KI Jakarta.

Saragih,B.1998. Kumpulan Pemikiran Agribisnis Paradigma Baru Pembangunan Ekonomi Berbasis Pertanian.Jakarta: CV.Nasional.

Suharno,B.Dan Amri,K.2002. Beternak Itik secara Intensif. Jakarta: Penebar Swadaya. 